\title{
A mídia e o golpe militar
}

\author{
AUDÁLIO DANTAS ${ }^{I}$
}

$\mathrm{N}$

O DIA 20 de junho de 1951 esboçavam-se as primeiras cenas de uma tragédia que abalaria o país três anos depois - o suicídio do presidente Getulio Vargas. Naquele dia, as bancas de jornal do Rio de Janeiro, então capital da República, receberam pilhas de um novo jornal, Última Hora, que aparecia com nova cara, diferente de todos os veículos de imprensa até então publicados. Vinha com nova paginação, títulos chamativos, em cores, grandes espaços ocupados por fotografias e, principalmente, escrito em linguagem direta, de fácil compreensão pelo público.

As diferenças não se limitavam a inovações editorias e gráficas: o novo jornal surgia com o claro objetivo de romper a "conspiração do silêncio" que predominava na quase totalidade dos grandes jornais, revistas, emissoras de rádio e televisão em relação ao governo de Getulio Vargas, que voltara ao poder pelo voto popular, nas eleições de 1950. Destacavam-se, entre eles, os mais importantes jornais editados no eixo Rio-São Paulo, como Correio da Manhã, Jornal do Brasil, Diário de Noticias e $O$ Estado de S. Paulo, aos quais se somavam os Diários Associados de Assis Chateaubriand, esses com alto poder de fogo, pois tinham edições em praticamente todos os estados.

A mídia refletia a reação da classe dominante, os conservadores e os chamados liberais que não aceitavam o resultado das urnas, das quais Vargas saíra vitorioso com $48 \%$ dos votos. Assim, em pouco tempo o silêncio foi cedendo lugar a uma campanha aberta contra o presidente. Um jornal, especialmente a Tribuna da Imprensa, de Carlos Lacerda, fazia o papel de porta-bandeira da reação.

Última Hora, dirigido pelo jornalista Samuel Wainer, que defendia o governo, obteve sucesso imediato, principalmente entre as camadas mais pobres da população. Além de atrair pela inovação gráfica, o jornal custava menos do que os demais e crescia em volume e tiragem, mais uma razão para a reação da mídia estabelecida. Não demorou a que se estabelecesse um verdadeiro duelo entre Última Hora e Tribuna de Imprensa.

Em meio a esse embate, a nova publicação era saudada nos meios profissionais como uma importante renovação do jornalismo brasileiro. Para muitos, o caráter inovador do jornal representava uma "revolução" na imprensa. Mas o impacto de seu lançamento marcaria, também, o início de sucessivas crises políticas que culminariam com o suicídio de Vargas e se prolongariam até o golpe militar de 1964. Com o aparecimento de Última Hora, começava a ser chocado o ovo da serpente que levaria o país a mergulhar na escuridão e na violência de 21 anos de ditadura. 
A história de Última Hora havia começado dois anos antes, quando Samuel Wainer, que trabalhava nos Diários Associados, foi enviado ao Rio Grande do Sul para fazer uma série de reportagens sobre a produção de trigo. Foi, então, que o repórter, atiladíssimo, tomou o rumo de uma casa perdida no meio do pampa gaúcho, sede da fazenda onde Getulio Vargas se refugiara depois da queda do poder, em 1945, com o fim da ditadura do Estado Novo por ele implantado em 1937.

Ali o ex-ditador vivia, tranquilo, o seu ostracismo. Na casa simples, de poucos e pobres móveis, quase miserável, o ex-ditador recebeu o repórter, que voltou para o Rio com uma reportagem-bomba: Getulio anunciava que voltaria ao poder. Disputaria o voto popular nas eleições de 3 de outubro de 1950, voltaria "nos braços do povo".

A reportagem teve enorme repercussão e serviria, pouco tempo depois, de porta de entrada para os cofres do Banco do Brasil, que garantiu parte substancial do capital necessário para a montagem do jornal Última Hora. Samuel Wainer, que se tornara amigo do presidente eleito, seria o comandante da operação.

A ideia da criação de um jornal começara a frutificar logo depois da publicação da reportagem, que sacudira os meios políticos, servindo de termômetro para Getulio avaliar o seu poder de fogo no embate eleitoral que se avizinhava. Agradecido, ele tornara-se amigo de Samuel Wainer e tratou de ajudá-lo na tarefa de montar o jornal.

Vargas antevia as dificuldades que teria de enfrentar com a imprensa, que durante a campanha eleitoral se unira contra sua volta ao poder. Já antes da posse ele considerava a necessidade de contar com um veículo de comunicação para enfrentar o fogo cerrado da mídia aliada aos setores mais conservadores do capital nacional e defensora dos interesses das grandes corporações internacionais que atuavam no país. Ao jornal de Samuel foi destinada a missão de enfrentar os poderosos donos da mídia comprometidos com esses interesses.

Não era uma missão fácil. Com o sucesso do vespertino, que aliava às inovações técnicas uma cobertura de qualidade, graças à contratação de profissionais recrutados entre os melhores, todos bem pagos, não tardariam as denúncias de favorecimento do governo, principalmente o financiamento concedido a Samuel Wainer pelo Banco do Brasil. Esse financiamento não constituía uma novidade entre as empresas editoras de jornais, mas no caso de Última Hora foi alardeado como um escândalo sem precedentes. Em seu livro $A$ história da imprensa no Brasil, Nelson Werneck Sodré (1966) observa que, ao providenciar o financiamento para a viabilização do jornal, Vargas considerara tratar-se de uma operação de rotina, um "caminho largamente batido" por grandes empresas jornalísticas. Mas essas pareciam atacadas de amnésia e fizeram do empréstimo a Última Hora o seu cavalo-de-batalha.

Registra Werneck Sodré (1966) no trabalho citado, até hoje considerado o mais importante já escrito sobre a história da imprensa brasileira: 
Toda a imprensa concentrou-se, então, em demonstrar o óbvio: que esse jornal (Última Hora) só se tornara possível pela concessão de grandes empréstimos nos estabelecimentos oficiais de crédito. Foi a "operação" que ocupou a grande imprensa em 1953 e que se arrastaria por alguns meses: era necessário por a descoberto os empréstimos levantados pelo vespertino oficioso, esquecendo aqueles levantados, nas mesmas condições, ou piores, pelos outros jornais.

Em longa nota de pé de página, Werneck alinha informações, de operações realizadas por empresas da grande imprensa junto a estabelecimentos oficiais de crédito, a começar pelo O Globo, de Roberto Marinho, que em cerca de dois anos, a partir de um primeiro empréstimo feito no Banco do Brasil em 17 de outubro de 1950, poucos dias depois da eleição de Vargas, portanto, conseguira outros que somavam mais de um milhão de dólares. Desde o primeiro empréstimo o favorecimento saltava aos olhos: $O$ Globo dava como garantia o penhor de uma máquina de impressão a ser adquirida graças ao empréstimo obtido. Nos empréstimos que obteria depois, novas máquinas a serem importadas, às quais se juntava uma velha rotativa Goss, já hipotecada, eram oferecidas como garantia.

As facilidades oferecidas a outros grupos jornalísticos não eram diferentes. Os Diários Associados de Assis Chateaubriand deviam ao Banco do Brasil, na época, 162 milhões de cruzeiros, enquanto o empréstimo concedido a Wainer para a montagem de seu jornal fora de Cr\$ 156 milhões. Isso não impedia, porém, que a campanha contra Última Hora prosseguisse, num crescendo que chegou, em 1953, à abertura de uma Comissão Parlamentar de Inquérito (CPI) na Câmara dos Deputados, por iniciativa do deputado Armando Falcão. Na justificativa de convocação da CPI Falcão acentua que a empresa editora controlada por Wainer "vem sendo contemplada, num regime de notório privilégio, com financiamentos maciços do Banco do Brasil, entidade de que é maior acionista o Tesouro Nacional". Para ele, a reação da grande imprensa contra Wainer se assentava no princípio da legítima defesa:

Em face da maneira ousada pela qual o repórter Samuel Wainer, jornalista profissional desprovido de patrimônio, acabava de entrar no elenco dos proprietários dos grandes órgãos de imprensa, $[\ldots]$ os tradicionais competidores, ameaçados por uma guerra de conquista, uniram-se para enfrentar o novo adversário, que chegava ao teatro de operações com o bafejo do palácio presidencial. (Falcão, 1989)

Armando Falcão, que fora ministro da Justiça no governo democrático de Juscelino Kubitschek (1956-1961), viria a ocupar o mesmo cargo na ditadura (governo Geisel) no qual se revelou um aplicado censor.

Com a CPI iniciava-se uma verdadeira devassa nos negócios de Samuel Wainer, enquanto nenhuma denúncia de favorecimento a outras empresas jornalísticas chegou a ser apurada. Muitas das dívidas da mesma imprensa que alardeava o "escândalo" de Última Hora jamais foram saldadas. 


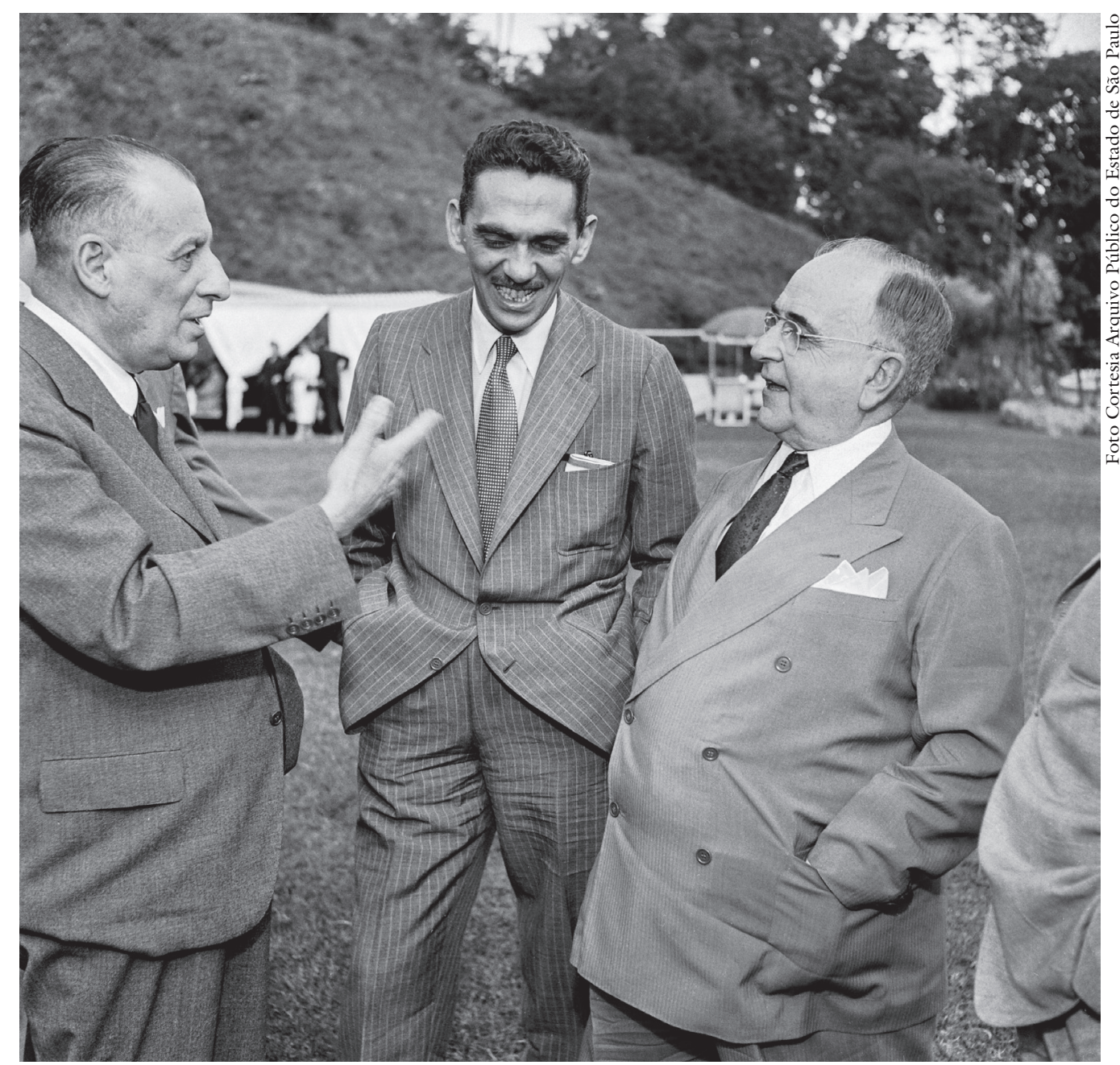

Samuel Wainer (no centro) participa em Petrópolis, no Rio, de evento com Getulio Vargas.

Mas as denúncias tinham outro objetivo: atingir o governo Vargas, que vinha, desde seu início, promovendo ou anunciando medidas que afetavam os interesses não só da mídia, mas os interesses econômicos das grandes empresas estrangeiras que elas defendiam. Uma dessas medidas limitava a remessa de lucros das empresas estrangeiras às suas matrizes no exterior. Mais do que isso, em 1953, depois de uma campanha que mobilizara milhões de brasileiros, a do "Petróleo é nosso", tramitava no Congresso Nacional o projeto que estabelecia o monopólio estatal do petróleo, que levaria à criação da Petrobras. E no ano seguinte Vargas enviava ao Congresso o Plano Nacional de Eletrificação, que criava a estatal Eletrobras.

Em 1954, a campanha da mídia, tendo à frente a Tribuna da Imprensa, já não se limitava ao empréstimo do Banco do Brasil a Última Hora. Outra denúncia contra Samuel Wainer ocupava manchetes: ele nascera na Bessarábia, era estrangeiro e, portanto, não poderia, de acordo com a lei, dirigir um jornal brasileiro. 


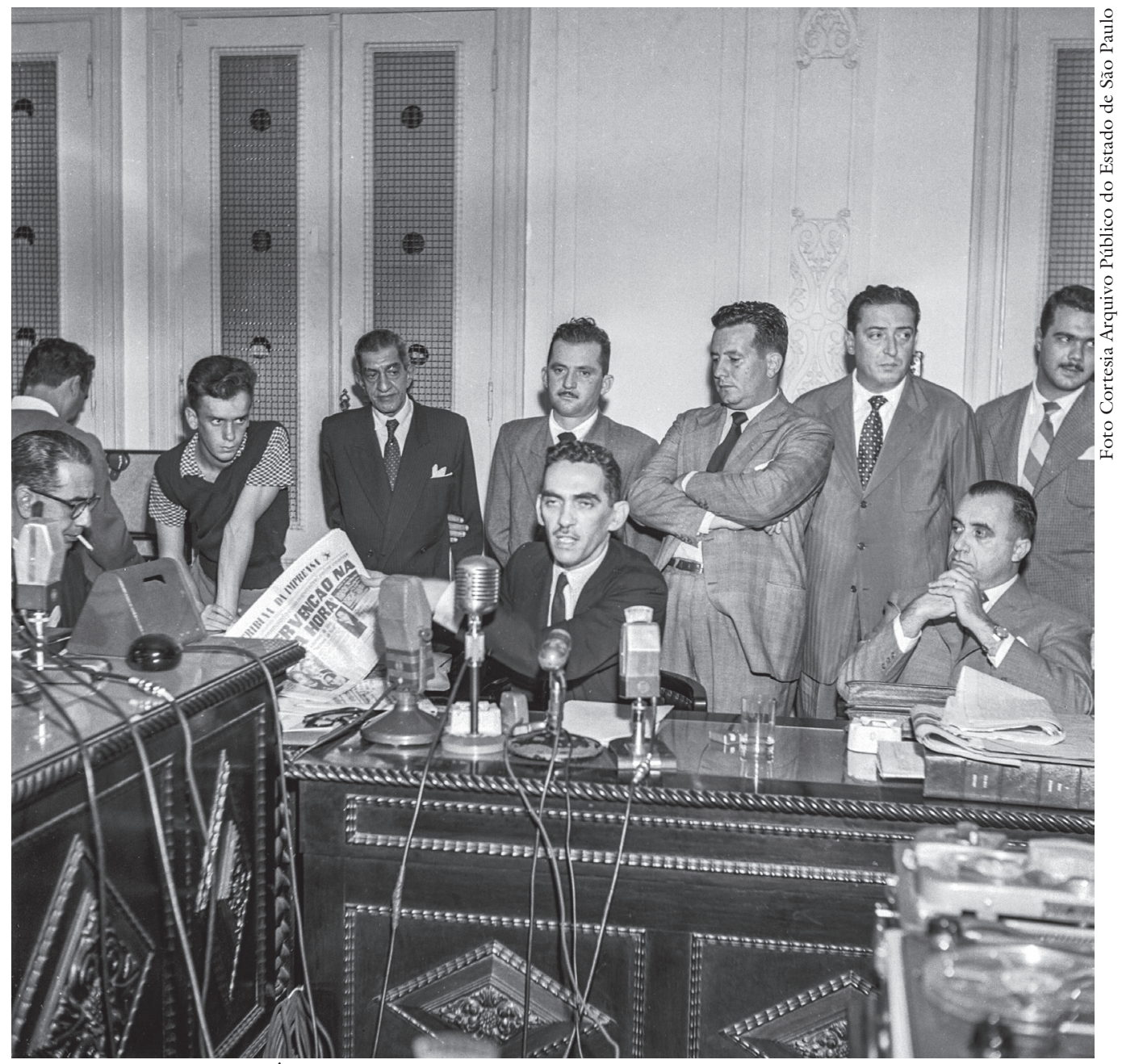

Com um exemplar de Última Hora em mãos, Samuel Wainer se defende na CPI da Câmara.

Logo as acusações se generalizaram. Falava-se em "mar de lama" e pregava-se abertamente um golpe contra Getulio. Em agosto de 1954 evoluía francamente uma conspiração para derrubar o governo. Os ânimos acirraram-se de parte a parte. A reação desordenada de setores do governo às provocações levaram a desastres como o atentado contra Carlos Lacerda, no dia 5 de agosto. O jornalista escapou com um tiro no pé, mas um major da Aeronáutica, Rubens Vaz, foi mortalmente atingido. Os acusados do atentado, logo presos, pertenciam à guarda pessoal de Getulio Vargas. Um deles era Gregório Fortunato, chefe da guarda presidencial.

Era o que faltava para a intensificação da tentativa de derrubada de Vargas. Os dezenove dias que precederam o suicídio do presidente, na madrugada do dia 24 de agosto, foram marcados por uma campanha sem precedentes da mídia. Em coro, os jornais desencadearam o que Werneck Sodré (1966, p.465) classifica como uma verdadeira blitz contra o presidente, o que "abalou o país, entorpeceu a opinião, acordada, súbita e furiosamente, pelo dramático gesto do 
presidente e pelo conteúdo do libelo terrível de sua carta-testamento". Sodré afirma, a seguir, "sem nenhum risco de erro", que as ofensivas da mídia, a partir de 1951, foram rigorosamente planejadas e desenvolvidas. Na verdade, faziam parte de um plano maior, de liquidação do governo de Getulio Vargas.

O suicídio de Vargas e a carta-testamento por ele deixada provocaram grande comoção em todo o país. No documento, o presidente apontava uma "campanha subterrânea de grupos internacionais" aliados a "grupos nacionais", organizada para barrar as medidas de caráter nacionalista que vinha tomando. No final da carta, dramaticamente, Getulio afirmava: "Lutei contra a espoliação do Brasil. Lutei contra a espoliação do povo. [...] Eu vos dei a minha vida. Agora vos ofereço a minha morte".

A tragédia frustrou o golpe longamente arquitetado.

A reação da opinião pública, que vinha sendo meticulosamente preparada para a aceitação de uma solução para a crise, o que implicaria a saída de Vargas do poder, foi além dos lamentos pela morte do presidente. O povo tomou as ruas, em todo o país, em revolta. Quebraram-se vitrinas, atiraram-se pedras contra prédios de companhias estrangeiras. Em Porto Alegre foi incendiada a Rádio Farroupilha, dos Diários Associados. Outras instalações de jornais e emissoras de rádio foram atingidas. Afinal, a mídia era a face mais visível da conspiração contra Vargas.

No Rio de Janeiro, as bancas que expunham a Tribuna da Imprensa, carro-chefe da campanha, foram incendiadas. E a sede do jornal, na Rua do Lavradio, contra a qual foram atiradas pedras, esteve na iminência de ser invadida por uma multidão revoltada. Lacerda, que se encontrava em confabulação com coronéis da $\mathrm{FAB}$, pediu ajuda do Exército. Soldados foram enviados para dispersar a multidão. Em depoimento recente, o jornalista Villas-Bôas Corrêa lembra uma frase disparada por Carlos Lacerda, em meio ao clima de ameaças contra o seu e os demais jornais que haviam cerrado fileiras no movimento conspiratório: "O suicídio do Getulio estragou a nossa festa".

Mas as forças que Lacerda e outros senhores da mídia representavam não desistiram. Já no ano seguinte tentavam impedir a posse de Juscelino Kubitschek e João Goulart, eleitos presidente e vice-presidente da República, respectivamente. $\mathrm{O}$ argumento contra a posse, largamente difundido pela mídia, era o de que a vitória fora obtida por pequena margem de votos (Juscelino obtivera pouco menos de $36 \%$ dos votos). Repetia-se um discurso subversivo de um coronel, que falava, aludindo ao resultado das eleições, em "mentira democrática".

O movimento golpista envolvia setores militares da direita, principalmente na Marinha e na Aeronáutica, empenhados em impedir a volta do getulismo ao poder. A conspiração em marcha contava com o apoio de Carlos Luz, que na condição de presidente da Câmara dos Deputados assumira no início de novembro a Presidência da República, em substituição a Café Filho, o vice-presidente que substituíra Getulio em agosto de 1954 e se afastara do governo em virtude de uma crise cardiovascular. 
A conspiração avançava, com o respaldo da quase totalidade da mídia. Na Tribuna da Imprensa, o golpe era pregado com insistência. Lacerda repetia em seus artigos que os eleitos deveriam ser impedidos de tomar posse. Em artigo publicado no dia seguinte à posse de Carlos Luz, 9 de novembro, falava como porta-voz de um movimento que já considerava vitorioso:

É preciso que fique claro, muito claro, que o presidente da Câmara não assumiu o governo da República para preparar a posse dos senhores Juscelino Kubitschek e João Goulart. Esses homens não podem tomar posse, não devem tomar posse e não tomarão posse. [...] O governo Carlos Luz, nascido do consenso dos militares, só tem esse sentido: evitar a posse dos remanescentes da oligarquia. Só poderá ter esse conteúdo: afastar do poder os eleitos da minoria. (Silva, 1987, p.122)

Dois dias depois, 11 de novembro, o general Henrique Teixeira Lott, que se demitira na véspera do cargo de ministro da Guerra, desfecha um "movimento em defesa da legalidade democrática", um contragolpe que contou com o apoio das principais comandos do Exército, em todo o país. Vinte e cinco mil soldados ocupam as ruas do Rio de Janeiro.

A tentativa de golpe contra a posse dos eleitos termina em precipitada fuga de Carlos Luz, alguns de seus ministros e Carlos Lacerda, todos abrigados no Arsenal de Marinha e depois embarcados no cruzador Tamandaré. Encenava-se uma pantomima marítima: o cruzador rumava para Santos, de onde Carlos Luz rumaria para São Paulo, para ali estabelecer o seu "governo".

Já no dia 13, quando o Exército detinha o controle da situação em todo país, o cruzador Tamandaré estava de volta ao Rio de Janeiro. Os civis desembarcam sem serem molestados, entre eles Carlos Lacerda, o porta-voz, que pede asilo na embaixada de Cuba.

Juscelino e João Goulart tomam posse em 31 de janeiro de 1956, mas as tentativas de golpe continuam. Duas tentativas de sublevação, por oficias da Aeronáutica que pretendiam estabelecer focos de resistência ao governo em pontos remotos da Amazônia, Jacareacanga (1956) e Aragarças (1959), fracassaram.

Outras tentativas se sucederam, num crescendo a partir de 1961, com a renúncia de Jânio Quadros à Presidência da República e o movimento militar para impedir a posse do vice-presidente João Goulart.

O golpe final se daria em 1964.

A participação da mídia nos acontecimentos que levaram ao golpe militar de 1964 contribuiu de maneira decisiva para a implantação da ditadura que dominaria o país por 21 anos. Pode-se afirmar, sem temor de erro, que um único jornal, Última Hora, não aderiu ao golpe. No dia 2 de abril, acuado depois de depredada sua redação, o jornal vivia uma situação inversa à de 24 de agosto de 1954, quando o povo enfurecido atacou as redações de veículos que pregavam a queda de Getulio, entre os quais $O$ Globo e Tribuna da Imprensa, a edição daquele dia, com cerca de 400 mil exemplares, trazia em manchete a notícia do suicídio de Getulio Vargas. 


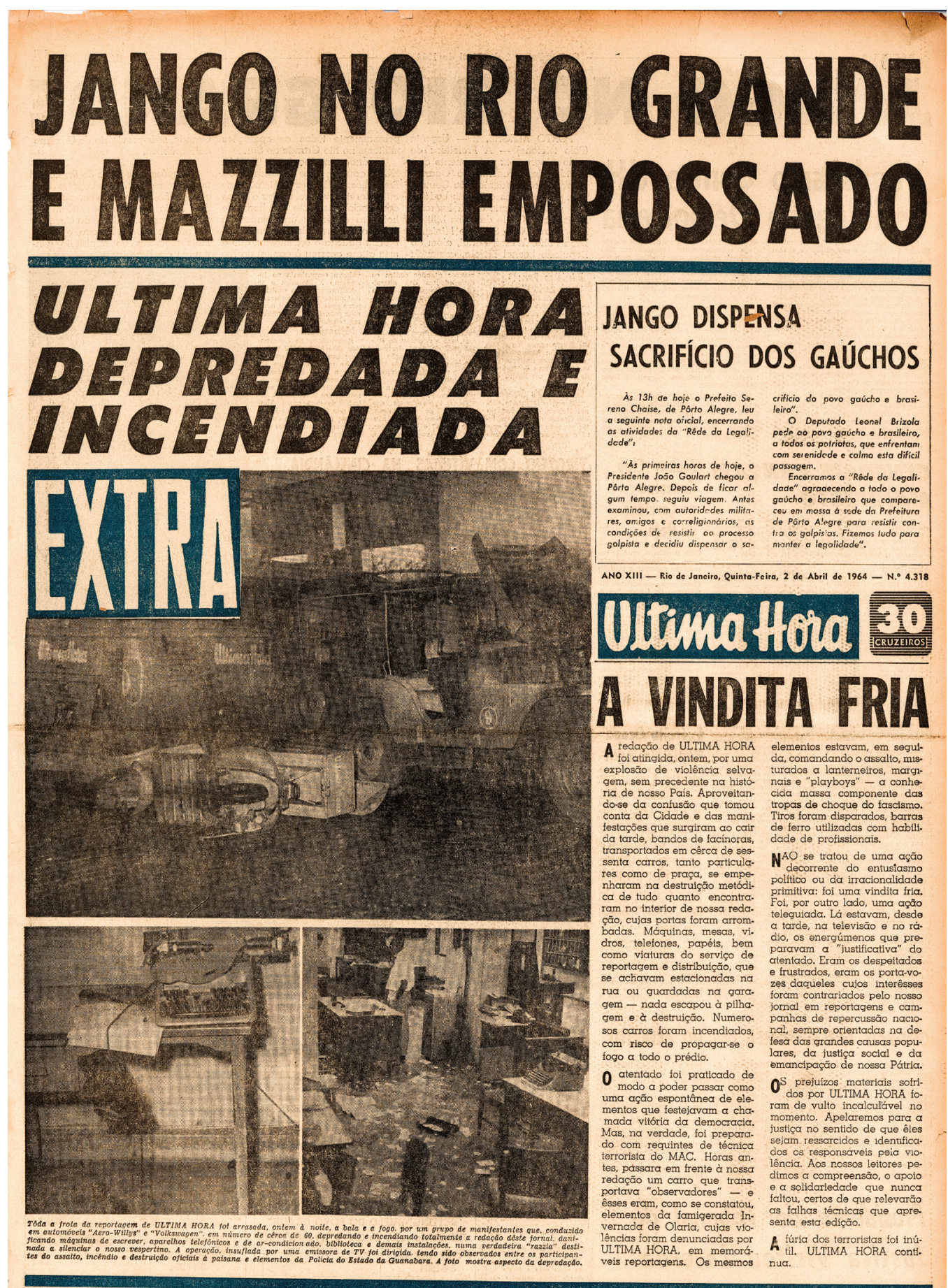

\section{TODA FROTA DE REPORTAGEM DESTRUIDA A BALA I I FOGO}

Fac-símile da capa da edição do jornal Última Hora, de Samuel Wainer, de 2 de abril de 1964. 
Os grandes jornais do eixo Rio-São Paulo vinham, simultaneamente à conspiração que avançava nos quarteis, ampliando a cada dia o espaço para respaldo ao movimento. Alguns desses veículos, como no caso de O Estado de $S$. Paulo e $O$ Globo, além do notório Tribuna da Imprensa, participavam ativamente da conspiração. Alguns dirigentes de grandes empresas jornalísticas faziam questão de alardear a sua condição de conspiradores. Em entrevista que me concedeu em 2005, o jornalista Ruy Mesquita, diretor do Grupo Estado, afirmou, ao ser perguntado sobre o apoio dado por seus jornais ao golpe: "Não só apoiamos, como conspiramos".

Esse alinhamento com o movimento golpista repetia a posição de amplos setores do empresariado, assustados com a possível implantação das reformas de base anunciadas com alarde pelo governo de João Goulart, inclusive em comícios em praça pública. O fantasma da tomada do poder pelo comunismo pairava no ar.

As grandes empresas jornalísticas cumpriam, assim, o papel que consideravam legítimo em defesa de seu capital. A mídia tornava-se poderoso instrumento ideológico na preparação e, mais tarde, no respaldo ao regime militar. Sua contribuição para a desestabilização do governo Goulart, que além de ser acusado de inepto era apontado como agente da infiltração comunista no Brasil, foi fundamental. Mesmo jornais de longa tradição liberal, como o Correio da Ma$n h \tilde{a}$, estiveram na linha de frente do processo de desestabilização do governo. Ficaram famosos dois editoriais publicados por esse jornal nos dias 31 de março e $1^{\circ}$ de abril, na agonia e na queda do governo Goulart. Os títulos - "Basta!" e "Fora!" - falavam por si. Clamavam pela deposição do presidente.

O apoio da imprensa ao golpe tem sido analisado em inúmeros trabalhos acadêmicos e, frequentemente, por jornalistas que acompanharam os acontecimentos que precederam o abril de 1964 e os duros dias que se seguiram, com a instauração do regime militar. O jornalista Jânio de Freitas, atualmente membro do Conselho Editorial da Folha de S.Paulo, ressalta:

Nem o Correio da Manhã escapou de um comprometimento que não deveria ser esquecido nunca por todos os que, em qualquer momento pensem ou falem da imprensa brasileira. Havia uma multidão de jornais em São Paulo e no Rio, imensa, mas todos se comprometeram em larga medida com o que de pior pode haver em termos de regime político, com uma falsa concepção de imprensa, um utilitarismo muito ordinário. Eu não vejo que jornal possa se isentar desse quadro. (in Blass; Bertol, 2010)

O tom de campanha adotado pela maioria da mídia contribuiria também, e de forma decisiva, para o engajamento da classe média no movimento que levaria à queda de Goulart. Multidões foram às ruas, em marchas cada vez mais concorridas. Dias depois da vitória do golpe, essas passeatas, antes denominadas Marchas da Família com Deus pela Liberdade, eram noticiadas pelos jornais como Marchas da Vitória. 
A vitória seria efusivamente festejada por toda a mídia. O título do editorial de $O$ Globo de 2 abril sintetiza a euforia: "Ressurge a democracia!". O texto começava dizendo que a nação "vive dias gloriosos" graças à intervenção dos militares. As duas principais revistas semanais, O Cruzeiro e Manchete, lançam edições extras, com textos grandiloquentes que exaltavam a vitória do movimento já então chamado de "revolução".

Nelson Werneck Sodré historia amplamente os antecedentes do golpe e o papel desempenhado pela imprensa no processo que levaria à quebra da legalidade democrática, em nome do combate ao comunismo. Ele aponta a atuação de agências de publicidade norte-americanas que atuavam no Brasil, detentoras de contas de grandes empresas estrangeiras, como instrumentos de cooptação da mídia, por meio da distribuição de verbas publicitárias. Jornais, revistas, emissoras de rádio e TV eram financiados; os veículos que se recusavam a participar do esquema, que incluía a publicação de matérias pagas sem serem caracterizadas como tal, eram discriminados na destinação de verbas publicitárias. Um boletim intitulado Ação Democrática chegou a publicar listas de empresas que anunciavam em publicações consideradas de esquerda, como Última Hora, apontando-as como financiadoras do comunismo.

Sodré (1966) cita que, paralelamente ao controle da mídia, desenvolviam-se as atividades de entidades destinadas ao financiamento de candidatos "anticomunistas" em eleições parlamentares. Uma delas, o Instituto Brasileiro de Ação Democrática (Ibad), recebia para tanto recursos do exterior. Outra, o Instituto de Pesquisas e Estudos Sociais (Ipes), constituído por empresários e militares, era voltada para ações "culturais". As atividades dessas entidades se avolumaram de tal maneira que levaram à criação de uma Comissão Parlamentar de Inquérito, perante a qual o tesoureiro do Ibad, Artur Oscar Junqueira, revelou que esse instituto financiara, nas eleições parlamentares de 1962, 250 deputados ou candidatos à Câmara. Esse financiamento alcançara a fabulosa quantia de cinco bilhões de cruzeiros (o salário mínimo na época era de 13.400,00 cruzeiros).

Os aplausos da mídia ao golpe não impediram que, uma vez instalados no poder, os militares desfechassem uma furiosa ofensiva contra participantes do governo deposto e cidadãos acusados de atividades esquerdistas. Jornalistas, professores, intelectuais, cidadãos suspeitos de subversão foram presos e torturados; vários tiveram seus direitos políticos cassados. Rapidamente o golpe que fora saudado como uma revolução revelava a sua verdadeira face.

Pouco mais de uma semana depois do golpe, os militares formaram o que chamaram de Comando Supremo da Revolução. No dia 9 de abril editavam o Ato Institucional $\mathrm{n}^{\circ} \mathrm{l}$ (AI-1), que tudo podia, acima do Congresso Nacional e do Judiciário. Armados do AI-1, os militares podiam alterar a Constituição, cassar mandatos, suspender direitos políticos, decretar o Estado de sítio.

A mídia noticiava as medidas de arbítrio e silenciava sobre as ameaças que pesavam sobre o país e ela própria. Mas havia exceções. O Correio da Manhã, 
que investira furiosamente contra o governo Goulart, pregando a sua derrubada, assumiu corajosamente o seu papel de informar e de criticar a violência dos golpistas. Nesse sentido, adiantava-se a Última Hora, o único que não aderiria ao golpe, mas que então dava passos incertos, na ausência de Samuel Wainer, que se exilara logo depois da queda de Goulart. O Correio sustentou sua posição o quanto pôde, mas pagaria caro por isso. Resistiu bravamente, a despeito do boicote publicitário que sofreu. Menos de um ano depois do golpe viu sua publicidade encolher drasticamente; tentou romper o cerco, até fez concessões, cortando cabeças ilustres de sua redação, como foi o caso de Carlos Heitor Cony, que desde os primeiros dias de abril vinha assinando artigos de crítica violenta ao novo regime. Outros jornalistas importantes, entre os quais Antônio Callado, deixaram o jornal.

A resistência do Correio continuou, apesar de tudo. Dava ampla cobertura às manifestações de protesto contra o regime. Uma delas, marcante, a da "Passeata dos Cem mil" (28 de junho de 1968), de protesto pelo assassinato do estudante Edson Luís de Lima Couto, num confronto com a polícia, ocupou quase toda a primeira página e outras internas, com todos os detalhes do acontecimento. No dia 13 de dezembro, enquanto o Ministério e o Conselho de Segurança Nacional se reuniam no Palácio das Laranjeiras, com o então ocupante da presidência da República, marechal Costa e Silva, para baixar o Ato Institucional $\mathrm{n}^{\mathrm{O}} 5$ (AI-5), a redação do Correio da Manhã era invadida pela polícia. Jornalistas foram presos. Um deles, Oswaldo Peralva, diretor de redação, foi algemado pelas costas e jogado num camburão. Tempos depois, a própria dona do jornal, Niomar Muniz Sodré, também seria presa.

Com o AI-5 veio a censura, que se fazia a distância, e instalou-se na redação do Correio. O jornal foi, aos poucos, definhando. Morreria ingloriamente nas mãos de um grupo ligado a empreiteiras, que o havia arrendado no final de 1969.

Os censores chegaram também à redação de $O$ Estado de $S$. Paulo, que ficara longe do Correio no confronto direto com o poder militar, mesmo que dele discordasse desde a imposição do Ato Institucional $\mathrm{n}^{\circ} 2$, de 27 de outubro de 1965, que entre outras coisas extinguia os partidos políticos e tornava indireta a eleição para presidente da República.

A censura prévia ao Estado chegou antes mesmo da consumação do AI-5. Pode-se dizer que veio na véspera, 12 de dezembro, para impedir que um editorial escrito por seu diretor, Júlio de Mesquita Neto, chegasse a conhecimento público. Perto da meia-noite, o chefe da Polícia Federal, general Sílvio Correia de Andrade, telefonou para a redação querendo saber qual seria a manchete do dia seguinte. Logo mais, às duas da madrugada do dia 13, estava nas oficinas do jornal que estava em final de impressão. Mandou que parassem as máquinas e ordenou a apreensão dos exemplares impressos $\mathrm{O}$ editorial, intitulado "Instituições em frangalhos", tratava do episódio em que a Câmara dos Deputados negara a licença de cassação do deputado Márcio Moreira Alves, exigida pelo 
governo como punição pelo discurso em que o parlamentar atacara duramente o regime. Batia duro em Costa e Silva e mencionava "as contradições do artificialismo institucional que pela pressão das armas foi o país obrigado a aceitar".

O jornal driblara a ordem de apreensão e conseguira lançar mais de cem mil exemplares nas bancas, incluídos 80 mil do Jornal da Tarde, o vespertino do grupo. Isso levou o general-chefe da censura a marchar sobre as bancas e a recolher, furioso, exemplares que sacudia no ar, furioso, enquanto gritava: "Este jornal traiu a Revolução!".

No mesmo dia os censores, alguns de revólver à mostra, estavam na redação e nas oficinas. A censura prévia, de "corpo presente", permaneceria até 9 de janeiro de 1969, Mas, como acontecia nos outros veículos de comunicação, continuou sendo feita a distância, por telex ou telefone. Três anos mais tarde, em agosto de 1972, os censores voltaram a agir diretamente da redação e de lá só saíram em janeiro de 1975, quando o general Geisel determinou o fim da censura prévia no grupo Estado.

Isso não significou que as restrições à liberdade de informação tivessem terminado para todos os veículos. Mas foi, sem dúvida, uma sinalização para a grande imprensa em geral, que, mesmo censurada a distância, foi aos poucos, cautelosamente, abrindo mão da autocensura, sem deixar, porém, a prática da omissão, evitando bater de frente com o regime.

Ao general Geisel, que encontrava forte resistência entre os militares que se opunham ao seu projeto de distensão - na verdade uma tentativa de prolongar a ditadura -, interessava afrouxar os cordões que mantinham os jornais sob controle. Mas apenas na medida em que isso favorecia a publicação de notícias desfavoráveis à chamada linha dura. Para ele, não era uma questão de avançar no rumo da democracia, mas de enquadrar os militares que o desafiavam.

Nesse jogo, abrandavam-se os métodos de censura. Os grandes jornais, que rotineiramente recebiam listas de assuntos proibidos, viram-se de repente livres delas. Mas mantinham-se cautelosos. Avançariam, ainda que tateando, meses depois, quando abriram espaço para informar sobre o assassinato do jornalista Vladimir Herzog.

Nem toda a grande imprensa ficou livre da censura prévia. A revista Veja, a mais importante publicação semanal do país, vinha sob censura prévia desde 1974 e assim continuaria até 1976. Acontecimentos de grande importância como o assassinato de Herzog e a destituição do comandante do II Exército, general Ednardo Dávila Mello, não foram noticiados pela revista.

Quanto à imprensa alternativa, que de fato resistiu ao arbítrio, o furor censório manteve-se inalterado por todo o período ditatorial. Jornais foram proibidos de circular, tiveram edições inteiras apreendidas e, como no caso de O Pasquim, que resistia pelo humor, seus diretores foram levados à prisão. Essas publicações, entre as quais se destacaram os semanários Opinião e Movimento, resistiram bravamente. Este último, que começou a circular em meados 1975, 
permaneceu sob censura prévia até 1978. Durante três anos não pôde publicar uma linha sequer sobre o caso Herzog. Os censores não se davam ao trabalho de comparecer à redação: exigiam que todo o material de cada edição - textos, fotos, vinhetas e até anúncios - fosse enviado à sede da Polícia Federal, em Brasília.

Outro jornal de combate, o Ex, conseguiu publicar em sua edição de novembro de 1975 extensa e impactante matéria sobre a escalada que levou ao assassinado de Herzog. Mas a ousadia lhe custou o desaparecimento, assim como aconteceu com outros jornais de resistência.

O panorama era outro nas redações da grande imprensa. As discordâncias de seus proprietários com o regime militar não impediam que eles se mantivessem bem comportados. Em muitos casos faziam a autocensura ou, pior, "limpavam" o noticiário produzido por seus repórteres. Foi o que aconteceu com o jovem repórter Ricardo Kotscho, que trabalhava no Estado ao mesmo tempo que cursava jornalismo na Escola de Comunicações e Artes da Universidade de São Paulo (ECA-USP). Ele cobria, em outubro de 1968, o conflito entre estudantes da Universidade Mackenzie, que seguiam orientação do Comando de Caça aos Comunistas (CCC), e da Faculdade de Filosofia da USP, comandados pela esquerda. Suas matérias eram reescritas, informações eram omitidas. O jornal era a favor da turma da direita e as alterações nos textos deixavam clara essa opção. O pessoal da Filosofia reclamava e o repórter tinha uma resposta pronta: "Não sou o dono do jornal".

Os donos dos jornais atravessaram o período da ditadura fazendo um jogo dúbio em que as cartas eram, na maioria das vezes, favoráveis ao regime. A maioria fez autocensura ou fingiu uma mais que suspeita neutralidade. Alguns, como nos casos de O Estado de S. Paulo e do Correio da Manhã, reagiram aos "desvios" autoritários dos militares, mas a maioria silenciou, não apenas por temor de represálias, mas por apoiar os desmandos da ditadura. Presidente do Sindicato dos Jornalistas de São Paulo em 1975, pude constatar que a omissão de informação era a praxe na grande imprensa. Antes do assassinato do jornalista Vladimir Herzog, em dependência do II Exército, em São Paulo, os militares da extrema-direita haviam desfechado uma operação de caça a jornalistas acusados de subversão. Em notas sucessivas, enviadas às redações, o Sindicato denunciava as prisões. Raramente essas notas eram publicadas; nenhum jornal ousou perguntar nada além daquilo que constava nos comunicados. Nada era apurado, nada era investigado.

Esse comportamento mudaria gradativamente a partir da morte de Herzog, quando O Estado de S. Paulo e o Jornal da Tarde, que já estavam livres da censura prévia, foram abrindo espaço cada vez maior para noticiar o caso. E não só noticiar como condenar a violência dos militares em editoriais candentes. Os demais jornais noticiavam cautelosamente, mesmo que privilegiando os comunicados oficiais, que ofereciam a versão de suicídio para a morte do jornalista. De qualquer modo era um avanço, o despertar de longos anos de silêncio. 
Nesse caso estava a Folha de S.Panlo, carro-chefe da empresa Folha da Manhã, comandado por Octavio Frias de Oliveira. Mas o grupo mantinha também a Folha da Tarde, um vespertino que assumira uma linha de esquerda antes do AI-5, mas que depois sofreu uma virada violenta, a ponto de ser considerado porta-voz da repressão política. Mas especificamente da Delegacia de Ordem Política e Social (Dops) e da Operação Bandeirante, que evoluiria para o Destacamento de Operações de Informações - Centro de Operações de Defesa Interna (DOI-Codi), onde Herzog foi morto sob tortura.

A Folha da Tarde era, praticamente, o avesso da Folha de S.Paulo, apesar da linha cautelosa e mesmo da concordância que essa mantinha em relação à ditadura militar. Em sua redação chegaram a trabalhar alguns policiais, em verdadeira dupla militância. Na verdade, militância a favor da ditadura. Havia acusações de que os carros do jornal serviam em operações da repressão política.

$\mathrm{O}$ caso Herzog escancarou o absurdo da existência de jornais tão diferentes editados pela mesma empresa. Enquanto a Folha de S.Paulo, com seus cuidados, informava com economia de espaço sobre os fatos que se seguiram ao assassinato do jornalista, a Folha da Tarde se esmerava em reforçar a versão dos militares. A manchete de primeira página do dia 27 de outubro, dois dias depois do ocorrido, anunciava: "Comunistas levam colega ao suicídio". E já no dia seguinte completava o serviço: "Herzog é sepultado e perícia confirma: suicídio".

A tragédia de Herzog servira, apesar das versões dos militares veiculadas pela Folha da Tarde, para espantar o fantasma da censura, que pairava em todas as redações. E, de modo marcante, contribuiu para substancial mudança na linha editorial da Folha de S.Panlo. Desde janeiro de 1969, quando a censura caiu pesadamente sobre toda a imprensa, o jornal de Octavio Frias deixara de publicar o editorial, tornando-se assim o único dos grandes jornais brasileiros a abrir mão do espaço destinado à sua opinião.

No dia seguinte ao culto ecumênico celebrado na catedral de São Paulo, no dia 31 de outubro de 1975, em memória do jornalista assassinado, a Folha estampava de volta o seu editorial. O culto, que levou oito mil pessoas à praça da Sé, realizara-se sem incidentes, ao contrário do que era esperado pelos militares, que haviam cercado a catedral e sitiado toda a cidade. Havia a ameaça de um massacre, a cidade e o país viveram momentos de grande tensão.

A Folha de S. Paulo expressou em seu editorial o alívio geral proporcionado pela realização do culto, sem incidentes. O alívio era exposto no título - "Lição e ponderação" -, enquanto o texto que se guia revelava um novo tom:

Uma lição para todos os radicais, de um e de outro lado, que vaticinavam catástrofes, esperando uma irrefreável escalada da subversão ou a violência indiscriminada de uma repressão. Uma ponderação de que o ocorrido está a recomendar maior vigilância no resguardo aos direitos inerentes à pessoa humana, para que tais fatos não mais se repitam em nosso país. 
Anos depois, quando o povo começou a tomar as ruas exigindo o fim do arbítrio, pelas eleições diretas para a Presidência da República, a Folha saía na frente, abrindo as suas páginas para aquelas que se constituiriam na maior manifestação de massa da história do Brasil.

Outros grandes jornais passaram a dedicar mais espaço à reação da sociedade civil, que se organizava em movimentos que se mostravam irreversíveis. Eles haviam engolido a censura ou convivido sem protesto com o arbítrio. Até que perceberem que a mercadoria que vinham entregando aos seus leitores - a informação - começava a não ser aceita, por falta de credibilidade.

\section{Referências}

ABRAMO, Z. W.; MAUÉS, F. Pela democracia, contra o arbitrio - A oposição democrática, do golpe de 1964 à campanha das Diretas Já. São Paulo: Editora Perseu Abramo, 2006.

ABREU, J. B. de. As manobras da informação. Rio de Janeiro: Mauad; Eduf, 2000.

AZEVEDO, C. Jornal Movimento - Uma reportagem. São Paulo: Editora Manifesto, 2011.

BLASS, S.; BERTOL, R. (Org.) Memória de repórter - Lembranças, casos e outras histórias de jornalistas brasileiros. Rio de Janeiro: Verso Brasil, 2010.

DANTAS, A. As duas guerras de Vlado Herzog - Da perseguição nazista na Europa à morte sob tortura no Brasil. Rio de Janeiro: Civilização Brasileira, 2012.

FALCÃO, A. Tudo a declarar. Rio de Janeiro: Nova Fronteira, 1989.

GASPARI, E. A ditadura encurralada. São Pulo: Cia. das Letras, 2004.

JORGE, F. Cale a boca, jornalista - O ódio e fúria dos mandões contra a imprensa brasileira. São Paulo: Novo Século, 2008.

KUSHNIR, B. Cães de guarda - Jornalistas e censores, do AI-5 à Constituição de 1988. São Paulo: Boitempo, 2004.

LIMA, V. A. de. Mídia - Crise politica e poder no Brasil. São Paulo: Fundação Perseu Abramo, 2006.

MATTOS, S. Mídia controlada - A história da censura no Brasil e no mundo. São Paulo: Paulus, 2005.

PEROSA, M. F. de L. Cidadania proibida - O caso Herzog através da imprensa. São Paulo: Imprensa Oficial, 2001.

SALDANHA, M. O país transtornado - Memórias do Brasil recente. Porto Alegre: Movimento, 2012.

SILVA, H. O poder militar no Brasil. Porto Alegre: L\&PM, 1987.

SODRÉ, N. W. História da imprensa no Brasil. Rio de Janeiro: Civilização Brasileira, 1966.

WILLIAM, W. O soldado absoluto - Uma biografia do marechal Henrique Lott. Rio de Janeiro: Record, 2006. 
RESUMO - Este artigo trata do papel desempenhado pela grande imprensa no processo político brasileiro, a partir do início dos anos 1950, com a volta ao poder, pelo voto popular, de Getulio Vargas, que sustentara a ditadura do Estado Novo até 1945, quando foi deposto pelos militares. Setores conservadores da direita moveram-lhe, com o apoio da mídia, campanha que terminou por levá-lo ao suicídio, em 1954. Várias tentativas de golpe se sucederam, até que em 1964, com o decidido apoio dos principais veículos de comunicação, um golpe militar implantou a ditadura no país. Esses mesmos veículos, alguns dos quais participaram diretamente da conspiração que levou à derrubada do governo constitucional de João Goulart, desempenharam papel importante como apoiadores da ditadura militar.

PALAVRAS-CHAVE: Getulio Vargas, Grande imprensa, João Goulart, Golpe de Estado, Ditadura militar.

ABSTRACT - This article outlines the role of the mainstream press in Brazil's political process since the early 1950s, with the return to power (by popular vote) of Getulio Vargas, who held the Estado Novo dictatorship until 1945, when he was deposed by the military. Conservative right-wing sectors, with support from the media, led a campaign against him, eventually leading to his suicide in 1954. Several attempted coups ensued until 1964, when, with resolute support from major media outlets, a military coup established a dictatorship in the country. These same media outlets, some of which participated directly in the conspiracy that led to the overthrow of the João Goulart's constitutional government, played an important role as supporters of the military dictatorship.

KErWORDS: Getulio Vargas, Mainstream press, João Goulart, Coup d'État, Military dictatorship.

Audálio Dantas é jornalista brasileiro. Foi presidente do Sindicato dos Jornalistas Profissionais no Estado de São Paulo. Elegeu-se deputado federal pelo MDB, em 1978. Em 2013, recebeu o prêmio "Intelectual do Ano - Troféu Juca Pato", conferido pela União Brasileira de Escritores. @ - comunicacao@audaliodantas.com.br

Recebido em 17.2.2014 e aceito em 5.3.2014.

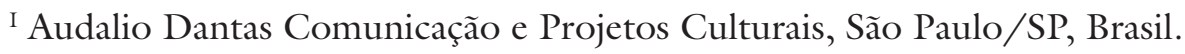

